Correspondence

Alasdair Cook

alasdair.cook@uni-konstanz.de

\title{
Dissimilation of cysteate via 3-sulfolactate sulfo-lyase and a sulfate exporter in Paracoccus pantotrophus NKNCYSA
}

\author{
Ulrike Rein, ${ }^{1}$ Ronnie Gueta, ${ }^{1}$ Karin Denger, ${ }^{1}$ Jürgen Ruff, ${ }^{1}$ \\ Klaus Hollemeyer ${ }^{2}$ and Alasdair M. Cook ${ }^{1}$ \\ ${ }^{1}$ Department of Biology, The University, D-78457 Konstanz, Germany \\ ${ }^{2}$ Institute of Biochemical Engineering, Saarland University, Box 5011 50, D-66041 \\ Saarbrücken, Germany
}

\begin{abstract}
Paracoccus pantotrophus NKNCYSA utilizes $(R)$-cysteate (2-amino-3-sulfopropionate) as a sole source of carbon and energy for growth, with either nitrate or molecular oxygen as terminal electron acceptor, and the specific utilization rate of cysteate is about 2 mkat (kg protein) ${ }^{-1}$. The initial degradative reaction is catalysed by an $(R)$-cysteate : 2-oxoglutarate aminotransferase, which yields 3-sulfopyruvate. The latter was reduced to 3-sulfolactate by an NAD-linked sulfolactate dehydrogenase [3.3 mkat ( $\mathrm{kg}$ protein $\left.)^{-1}\right]$. The inducible desulfonation reaction was not detected initially in cell extracts. However, a strongly induced protein with subunits of $8 \mathrm{kDa}(\alpha)$ and $42 \mathrm{kDa}(\beta)$ was found and purified. The corresponding genes had similarities to those encoding altronate dehydratases, which often require iron for activity. The purified enzyme could then be shown to convert 3-sulfolactate to sulfite and pyruvate and it was termed sulfolactate sulfo-lyase (Suy). A high level of sulfite dehydrogenase was also induced during growth with cysteate, and the organism excreted sulfate. A putative regulator, OrfR, was encoded upstream of suy $A B$ on the reverse strand. Downstream of suy $A B$ was suyZ, which was cotranscribed with suy $B$. The gene, an allele of tauZ, encoded a putative membrane protein with transmembrane helices (COG2855), and is a candidate to encode the sulfate exporter needed to maintain homeostasis during desulfonation. suy $A B$-like genes are widespread in sequenced genomes and environmental samples where, in contrast to the current annotation, several presumably encode the desulfonation of 3-sulfolactate, a component of bacterial spores.
\end{abstract}

\section{INTRODUCTION}

$(R)$-Cysteate (L-cysteate; 2-amino-3-sulfopropionate, Fig. 1) is a natural product first found in wool, and it is now known as an intermediate in cysteine metabolism involved in, for example, the synthesis of taurine (2-aminoethanesulfonate) in mammals (Consden et al., 1946; Weinstein \& Griffith, 1988). The compound also serves as a precursor of the cytophagal sulfolipid capnine (White, 1984) and is found extracellularly in spiders' webs (Vollrath et al., 1990). Cysteate serves as a sole source of carbon and energy for the aerobic growth of bacteria (Stapley \& Starkey, 1970), as an electron acceptor for several sulfate-reducing bacteria (Lie et al., 1996, 1998, 1999; Laue et al., 1997a), as an electron donor for some nitrate-reducing bacteria (Denger et al., 1997; Mikosch et al., 1999), and as the substrate for a

The GenBank/EMBL/DDBJ accession numbers for the sequences in P. pantotrophus NKNCYSA reported in this paper are: orfR and suyABZ, AY704413; extension of the gene sequence in the tau region to include most of tauZ, AY498615. fermentation in a sulfate-reducing bacterium (Laue et al., 1997b). None of those papers reports a degradative pathway, but Mikosch et al. (1999) did observe 2-oxoglutaratedependent transamination of cysteate to 3-sulfopyruvate (EC 2.6.1.-) in Paracoccus pantotrophus NKNCYSA and regeneration of the 2-oxoglutarate (EC 1.4.1.4) (Fig. 1). Neither taurine dehydrogenase (presumably EC 1.4.2.-) nor sulfoacetaldehyde acetyltransferase (EC 2.3.3.15), which are induced in $P$. pantotrophus NKNCYSA during dissimilation of taurine (Ruff et al., 2003; Brüggemann et al., 2004), is observed during growth with cysteate (K. Denger, unpublished), so the major cysteate transformation known in mammalian tissue, decarboxylation to taurine (Weinstein \& Griffith, 1988), is not used in P. pantotrophus.

3-Sulfopyruvate and 3-sulfolactate are established natural products (e.g. Bonsen et al., 1969; Graupner et al., 2000a) whose degradative pathway in prokaryotes is unknown (e.g. Roy et al., 2003). Sulfopyruvate is subject to reduction to $(S)$-sulfolactate by 3 -sulfolactate dehydrogenase (EC 1.1.1.272) in, for example, the biosynthesis of coenzyme 
(a)

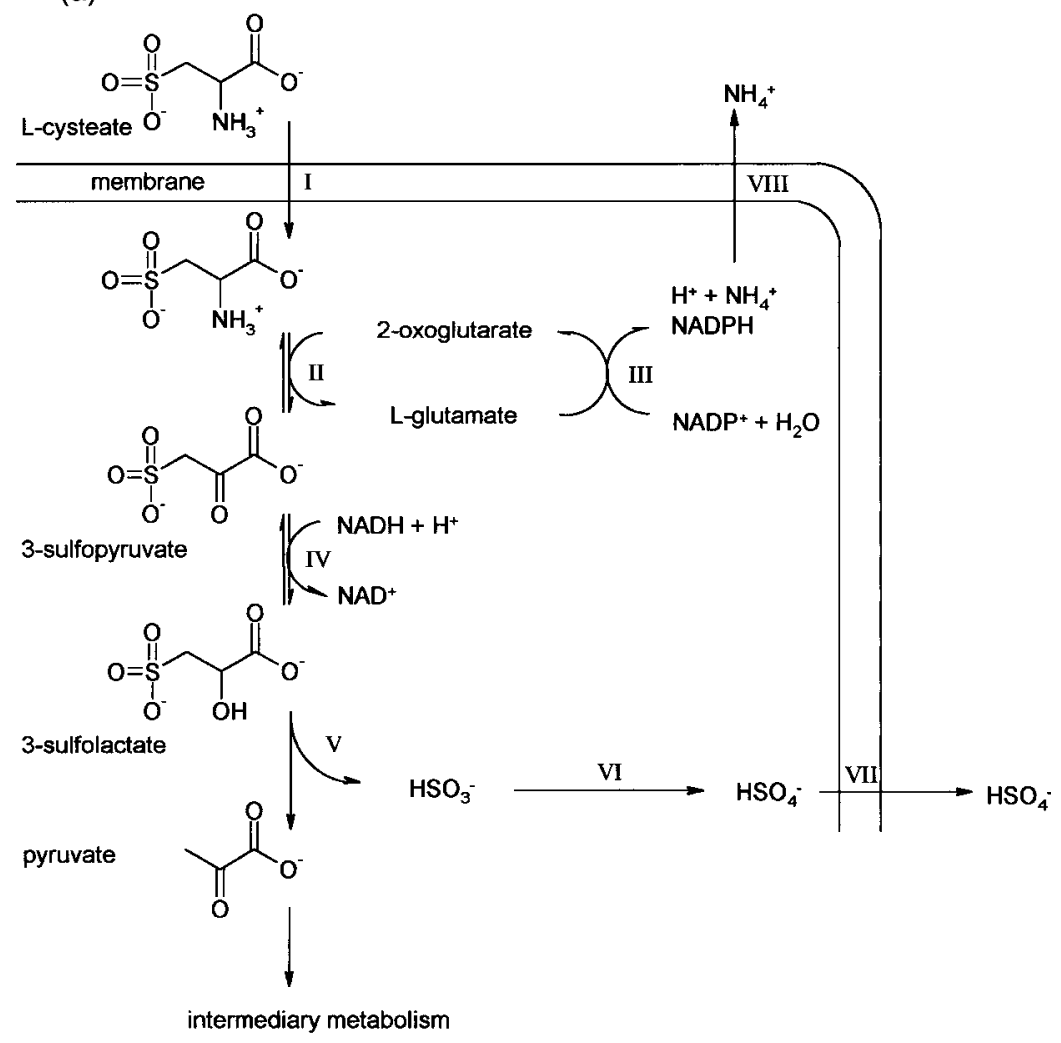

(b)

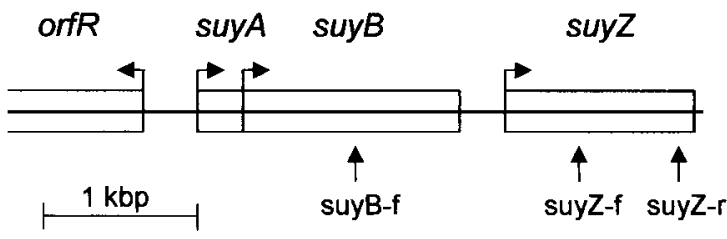

Fig. 1. Transport and biochemical reactions involving sulfonated compounds in the degradative pathway of cysteate (a) and the organization of the cluster of suy genes (b) in P. pantotrophus NKNCYSA. This pathway, in which initially only reactions II and III were established (Mikosch et al., 1999), was developed as a working hypothesis when a partial sequence of suy $B$ became available (see text); the components of ionic homeostasis were developed from earlier work (Brüggemann et al., 2004). Reaction I is an as yet undefined transport system. Reaction II is L-cysteate: 2-oxoglutarate aminotransferase. Reaction III is L-glutamate dehydrogenase. Reaction IV is sulfolactate dehydrogenase. Reaction $\mathrm{V}$ is sulfolactate sulfo-lyase (SuyAB). Reaction $\mathrm{VI}$ is sulfite dehydrogenase (EC 1.8.2.1). Reaction VII is sulfate export, and reaction VIII represents export of the ammonium ion. The gene cluster (b), which was discovered and sequenced in this work, involves at least four open reading frames, encoding a putative transcriptional regulator (OrfR), the sulfolactate sulfo-lyase (SuyAB) and the presumed sulfate exporter (SuyZ). The binding sites of the primers used for RT-PCR are shown with arrows.

M (Graupner et al., 2000a). The reaction can also be catalysed by mammalian malate dehydrogenase (EC 1.1.1.37), where the resulting sulfolactate is excreted (Weinstein \& Griffith, 1986, 1988), but 3-sulfolactate dehydrogenase represents a specific lineage within the family of malate dehydrogenases (Graupner et al., 2000b). Sulfolactate is widespread as a component of bacterial endospores (Bonsen et al., 1969; Wood, 1971; see also Graham et al., 2002) and is now known to be an intermediate in one pathway of degradation of sulfoquinovose (Roy et al., 2003).

Our initial hypothesis for the desulfonation reaction in cysteate degradation in the nitrate-reducing strain NKNCYSA was based on the only characterized, nonoxygenolytic mechanism known, catalysed by sulfoacetaldehyde acetyltransferase (EC 2.3.3.15). This hypothetical, thiamin-diphosphate-dependent reaction would involve sulfopyruvate, and would yield acetyl phosphate. There was, however, an inducible protein of unknown function in extracts of cysteate-grown cells. This protein was purified, and the corresponding gene was sequenced. Sequence similarity to the enolase superfamily allowed the reaction mechanism of sulfolactate sulfo-lyase (Suy) and the overall pathway to be hypothesized (Fig. 1). The hypothesis was tested in this paper.

The degradative pathways of cysteate and taurine are independent of one another, but they share poorly understood characteristics. Growth with each compound as a carbon source is accompanied by excretion of both ammonium and sulfate ions (Mikosch et al., 1999; Brüggemann et al., 2004) (Fig. 1). These are presumably homeostatic mechanisms to maintain constant ionic conditions within the cell, and neither process is understood (Brüggemann et al., 2004; see also Denger et al., 2004).

Evidence is now presented that the desulfonative pathway of the $\mathrm{C}_{3}$-sulfonates cysteate, sulfopyruvate and sulfolactate in $P$. pantotrophus NKNCYSA involves inducible sulfolactate sulfo-lyase (SuyAB), a novel member of the altronate dehydratases, orthologues of which seem to be encoded on many genomes. It is further proposed that the gene (suyZ) downstream of $\operatorname{suy} A B$ encodes a sulfate exporter, which is also widespread. 


\section{METHODS}

Materials. (R)-Cysteic acid monohydrate ( $>99 \%)$ was from Fluka. Authentic 3-sulfopyruvate was kindly supplied by R. H. White (cf. White, 1986). 3-Sulfopyruvate (Denger et al., 2001) and 3sulfolactate (Roy et al., 2003) were synthesized and identified as described elsewhere. The sulfolactate had a specific optical rotation of $-0 \cdot 7^{\circ}$, whereas the literature values for D- and L-sulfolactate are $+3 \cdot 5^{\circ}$ and $-3 \cdot 1^{\circ}$, respectively (Graham \& White, 2002): our synthetic material was effectively racemic. Commercial chemicals were of high purity (about 99\%), from Sigma-Aldrich, Fluka or Merck and they were used as supplied by the manufacturer. Sulfoacetate was from Fisher Scientific. Gases $\left(\mathrm{N}_{2}, \mathrm{CO}_{2}\right)$ were obtained from Messer Griesheim.

Growth media and organisms used. Most experiments were done with bacteria grown in basal salts medium representing fresh water, buffered with $50 \mathrm{mM} \mathrm{NaHCO}$, and prepared anoxically as described by Widdel \& Pfennig (1981). The supplements and alterations used to provide conditions for nitrate reduction, sulfonate reduction or fermentation were described elsewhere (Laue et al., 1997b; Mikosch et al., 1999). P. pantotrophus NKNCYSA (DSM 12449) (Mikosch et al., 1999), Desulfovibrio sp. strain RZACYSA, Bilophila wadsworthia RZATAU (DSM 11045) (Laue et al., 1997a) and Desulfovibrio sp. strain GRZCYSA (DSM 11493) (Laue et al., 1997b) were used. Desulfitobacterium hafniense DCB-2 was kindly made available by J. Tiedje, East Lansing, MI, USA. Strain DCB-2 grew with 3-sulfolactate as the electron acceptor and lactate as the electron donor when the medium was supplemented with $0 \cdot 1 \%$ yeast extract. The growth medium for cells grown under oxic conditions is indicated in Brüggemann et al. (2004). Cupriavidus necator (Ralstonia eutropha) JMP134 (DSM 4058) (Vandamme \& Coenye, 2004) and Novosphingobium aromaticivorans (DSM $12444^{\mathrm{T}}$ ) were obtained from the German Culture Collection (DSMZ, Braunschweig, Germany).

Permeabilized cells. Cell suspensions $\left(0.4 \mathrm{mg}\right.$ protein $\mathrm{ml}^{-1}$, $1 \mathrm{ml}$ ) were incubated for $10 \mathrm{~min}$ at $37^{\circ} \mathrm{C}$ in $0 \cdot 1 \mathrm{M}$ Tris/ $\mathrm{HCl}$ buffer, $\mathrm{pH} 7 \cdot 5$, which contained $5 \mathrm{mM} \mathrm{MgCl}_{2}$ and cetyltrimethylammonium bromide $\left[0 \cdot 25 \mathrm{mg}(\mathrm{mg} \text { protein })^{-1}\right]$ before the reaction was started with the addition of $1-2 \mathrm{mM}$ substrate. Thereafter, samples were taken at intervals to determine concentrations of substrate and of possible products.

Preparation of cell-free extracts and nucleic acids. Cells for the preparation of cell-free extract were harvested $(13000 \mathrm{~g}, 20 \mathrm{~min}$, $4{ }^{\circ} \mathrm{C}$ ) at the end of the exponential growth phase and disrupted by three passages through a chilled French pressure cell (140 MPa). Whole cells and debris were removed by centrifugation $(5000 \mathrm{~g}$, $20 \mathrm{~min}, 4^{\circ} \mathrm{C}$ ) to give the crude cell extract. Soluble and membrane fractions of the crude extract were obtained by ultracentrifugation $\left(150000 \mathrm{~g}, 2 \mathrm{~h}, 4^{\circ} \mathrm{C}\right)$. Nucleic acids were precipitated as described elsewhere (Ruff et al., 2003).

Enzyme measurements. (R)-Cysteate : 2-oxoglutarate aminotransferase was assayed discontinuously as disappearance of cysteate (Mikosch et al., 1999). Glutamate dehydrogenase (EC 1.4.1.4) was assayed photometrically (Schmidt, 1974). 3-Sulfolactate dehydrogenase was routinely assayed photometrically $(340 \mathrm{~nm})$ as sulfopyruvatedependent oxidation of $\mathrm{NADH}$ : the reaction mixture $(1 \mathrm{ml}$ final volume) contained $50 \mu \mathrm{mol}$ Tris/ $\mathrm{HCl}$ buffer, $\mathrm{pH} \mathrm{7 \cdot 5,} 0 \cdot 25 \mu \mathrm{mol}$ $\mathrm{NADH}, 2 \mu \mathrm{mol}$ sulfopyruvate and $15-30 \mu \mathrm{g}$ protein, with which the reaction was started. Occasionally, the reaction mixture was used to follow the conversion of sulfopyruvate to sulfolactate by ion chromatography. 3-Sulfolactate sulfo-lyase was assayed discontinuously at $30^{\circ} \mathrm{C}$ as disappearance of racemic 3 -sulfolactate and formation of sulfite and pyruvate. The reaction mixture $(2 \mathrm{ml})$ contained $200 \mu \mathrm{mol} \mathrm{MOPS} / \mathrm{NaOH}$ buffer, pH 6.5, $2 \mu \mathrm{mol} \mathrm{FeCl}_{2}, 5 \mu \mathrm{mol}$ sulfolactate and 2-4 mg protein, with which the reaction was started. Samples were taken at intervals: (a) $200 \mu$ l to acetonitrile $(100 \mu \mathrm{l})$ for the determination of sulfolactate by ion chromatography; (b) $50 \mu \mathrm{l}$ to solution A (950 $\mu \mathrm{l})$ (Denger et al., 2001) for the determination of sulfite as the fuchsin adduct; (c) $50 \mu \mathrm{l}$ to $2 \mathrm{M} \mathrm{HCl}$ $(10 \mu \mathrm{l})$ for the enzymic quantification of pyruvate after removal of protein by centrifugation ( $2 \mathrm{~min}, 20000 \mathrm{~g}$, room temperature). Sulfite dehydrogenase (EC 1.8.2.1) was assayed photometrically with cytochrome $c$ as electron acceptor (Reichenbecher et al., 1999). Pyruvate disappearance was assayed discontinuously at $37^{\circ} \mathrm{C}$ : the reaction mixture ( $1 \mathrm{ml}$ final volume) contained $100 \mu \mathrm{mol}$ potassium phosphate buffer, $\mathrm{pH} 7 \cdot 5,2-4 \mathrm{mg}$ protein and $2 \mu \mathrm{mol}$ pyruvate, with which the reaction was started. Samples $(100 \mu \mathrm{l})$ were taken at intervals into $20 \mu \mathrm{l} 2 \mathrm{M} \mathrm{HCl}$ and the concentration of pyruvate was determined after derivatization.

Protein purification. Anion-exchange chromatography was done as described previously (Denger et al., 2001). The buffer was modified to include $10 \mu \mathrm{M}$ pyridoxal 5 '-phosphate. Each fraction was assayed for $(R)$-cysteate:2-oxoglutarate aminotransferase, sulfite dehydrogenase and glutamate dehydrogenase; the presence of the $42 \mathrm{kDa}$ protein was detected by SDS-PAGE.

The fraction which contained the $42 \mathrm{kDa}$ protein was concentrated, rebuffered and subjected to hydrophobic interaction chromatography on Phenyl Superose HR (5/5 column; Pharmacia). A linear decreasing gradient from $1.7 \mathrm{M}$ ammonium sulfate in $20 \mathrm{mM}$ Tris/sulfate, $\mathrm{pH} 7 \cdot 5$, and containing $10 \mu \mathrm{M}$ pyridoxal $5^{\prime}$-phosphate, was applied. The $42 \mathrm{kDa}$ protein eluted at $0 \mathrm{M}$ ammonium sulfate.

Analytical methods. The HPLC system was equipped with a diode array detector, and used for reverse-phase chromatography (Laue et al., 1996). Cysteate was quantified by HPLC after derivatization with 2,4-dinitrofluorobenzene (DNFB) (Sanger, 1945) as described elsewhere (Denger et al., 1997). Pyruvate was routinely derivatised with 2,4-dinitrophenylhydrazine, and measured photometrically at $450 \mathrm{~nm}$; pyruvate was also determined enzymically with lactate dehydrogenase (Lamprecht \& Heinz, 1984). Pyruvate was identified by MALDI-TOF MS after derivatization (Tholey et al., 2002). 3Sulfopyruvate was determined as the azine formed by reaction with 2-(diphenylacetyl)indane-1,3-dione-1-hydrazone (Cunningham et al., 1998) after separation by HPLC with UV detection (400 nm). A perchlorate mobile phase with a gradient of acetonitrile (30-80\%) was used (cf. Schleheck et al., 2000). Nitrate, nitrite and sulfoacetate, and occasionally sulfolactate, sulfopyruvate, 2-oxoglutarate, glutamate, sulfate and sulfite, were separated on an LCA 3AS or A03 column by ion chromatography with suppression and quantified in a conductivity detector (Laue et al., 1996). Sulfate was measured as the attenuance of a suspension of insoluble $\mathrm{BaSO}_{4}$ (Sörbo, 1987). Sulfite was quantified photometrically as the fuchsin adduct (Denger et al., 2001).

Protein in whole cells was assayed by a Lowry-type reaction (Kennedy \& Fewson, 1968). Protein in extracts was assayed by protein-dye binding (Bradford, 1976). Denatured proteins were separated in $12 \%$ SDS-PAGE gels and stained with Coomassie Brilliant Blue R250 (Laemmli, 1970); molecular masses of bands were determined by comparison with standard proteins (Low Range Marker Proteins, BioRad). The N-terminal amino acid sequence of a blotted protein was determined after Edman degradation, as indicated previously (Schläfli et al., 1994). The sequences of internal peptides were obtained by Edman degradation after proteolysis (Lys C) of the separated protein and separation of the peptides by HPLC (Top-Lab Service Facility, München, Germany). Total bacterial DNA was prepared by phenol/ chloroform extraction (Ausubel et al., 1987). The DNA sequence of the putative 3-sulfolactate sulfo-lyase genes, with those of the upstream and downstream genes (Fig. 1b), was generated by PCR, cycle sequencing (BigDye ABI-technology at GATC, Konstanz), primer 
walking and the GenomeWalker approach (BD Biosciences, Clontech) (Denger et al., 2001; Tralau et al., 2003b). The initial PCR-primers were suy1-f, TTYWSIAAYGCIACIGTIARGC; suy2-f, ACGCAGGTGATCGTCGACG; suy3-r, CKDATIGTYTCRAARTCICC; suy4-r, ACITTYTCYTCYTCDATNGTNGTIARICCI. Sequence analysis was done using the DNASTAR Lasergene program package. The NCBI BLAST programs (http://www.ncbi.nlm.nih.gov/blast/), or analogues in the TIGR website (http://www.tigr.org/tdb/mdb/mdbinprogress.html) and the Transport Classification Database (TCDB) (http://tcdb.ucsd. $\mathrm{edu} / \mathrm{tcdb} /$ ), were used to search for similarities amongst the new and established sequences (Altschul et al., 1997). The PROSITE tools of the Swiss Institute of Bioinformatics were used to search for motifs in the SWISS-PROT database on the ExPASy server (http://www. expasy.org/). The predictions of transmembrane helices were generated by the TMHMM server (http://www.cbs.dtu.dk./services/). Reversetranscription PCR (RT-PCR) was done as described previously (Tralau et al., 2003a), with $0 \cdot 4 \mu \mathrm{g}$ total RNA from cultures in the mid-exponential phase of growth; the Taq polymerase was from Genaxxon. The following primers were used: suyZ-f, GATCATCAGGACGCGCGGGA; suyZ-r, ACCAGGACGACAGCGGCGGA; tauZ-f: TCCACCATGATCCCTTCGC; tauZ-r: AAAGCCCGGCCAGCATCGGG; suyB-f; ACCAAGGGCAACATTCTTGG. The PCR programme consisted of 10 cycles with an initial annealing temperature of $60{ }^{\circ} \mathrm{C}$ and a decrement of $0.5{ }^{\circ} \mathrm{C}$ (touch-down) followed by 25 cycles with an annealing temperature of $57^{\circ} \mathrm{C}$; the extension time was $1 \mathrm{~min}$ at $72^{\circ} \mathrm{C}$.

The sequence data on Burkholderia xenovorans LB400, Burkholderia sp. R18194 (cepacia-like), Cupriavidus necator JMP134, Desulfitobacterium hafniense DCB-2, Novosphingobium aromaticivorans SMCC F199, Rhodobacter sphaeroides 2.4.1, Rubrobacter xylanophilus DSM 9941 and Trichodesmium erythraeum IMS101 were generated by the US Department of Energy's Joint Genome Institute and are publicly available at http://www.jgi.doe.gov. Sequence data on Silicibacter pomeroyi DSS $-3^{\mathrm{T}}$, and information on funding the project, were obtained from The Institute for Genomic Research through the website at http://www.tigr.org. The accession number for clone P1023 in the Leishmania major genome project is AC091510. The other genomic sequences were from published data.

\section{RESULTS}

\section{Chemically defined reactions from cysteate to pyruvate and sulfate}

The presence of cysteate:2-oxoglutarate aminotransferase and of NADP-coupled glutamate dehydrogenase in extracts of cells of $P$. pantotrophus NKNCYSA grown with cysteate under anoxic conditions was confirmed (Mikosch et al., 1999) and found in addition in cells grown under oxic conditions (not shown). These extracts also caused disappearance of 3-sulfopyruvate, in the presence of $\mathrm{NADH}$, and the appearance of a compound which co-chromatographed with authentic 3-sulfolactate in an ion chromatograph. Boiled extract caused no reaction. The specific activity of the sulfolactate dehydrogenase was 42 mkat (kg protein $)^{-1}$. Each of these three enzymes was present at high levels under all conditions measured (e.g. acetate-grown and cysteategrown cells) (not shown).

Whole cells of cysteate-grown $P$. pantotrophus did not degrade 3-sulfopyruvate, whereas permeabilized cells did so. We presume that the organism has no transport system for 3-sulfopyruvate, and that the cell membrane is impermeable to organosulfonates (see Graham et al., 2002). The organism obviously has a transport system for cysteate, because it utilizes cysteate, and a transport system for sulfolactate, which it also utilizes.

Whole cells or permeabilized cells of $P$. pantotrophus released equimolar sulfate from the portion of sulfolactate that disappeared (not shown). No sulfite was detected. Initially, no disappearance of the substrate was detected in crude extracts, but we developed the hypothesis that an enolase-like reaction was catalysed (sulfolactate sulfo-lyase: reaction V in Fig. 1; see also Discussion) and altered the reaction mixture accordingly. Crude extract then converted sulfolactate to compounds which were tentatively identified as sulfite and pyruvate (Fig. 2). The stoichiometry was essentially $1: 1: 1$ (Fig. 2): in longer experiments (not shown), the formation of sulfate was detected. The identity of the sulfite, routinely assayed as an adduct of fuchsin, was confirmed by co-chromatography with authentic material in an ion chromatograph. The tentative identification of the pyruvate, initially determined in the specific reaction catalysed by lactate dehydrogenase, was supported by the colour reaction with 2,4-dinitrophenylhydrazine. The identification of pyruvate was confirmed by MALDITOF MS after reaction with 1,2-phenylendiamine as the quinoxalinol derivative in the positive-ion mode $(\mathrm{m} / z=161$ $\left.[M+\mathrm{H}]^{+}\right)$.

Sulfolactate sulfo-lyase was found in cysteate- and sulfolactate-grown cells only. None was found in extracts of acetate-, taurine-, isethionate- or sulfoacetate-grown cells. Sulfolactate sulfo-lyase was considered to be inducible.

The reaction in Fig. 2 had largely ceased within $30 \mathrm{~min}$, with about $50 \%$ of the substrate remaining. When more substrate was added, a rapid reaction was observed which largely ceased when $50 \%$ of the added material remained. Thereafter, there was a slow disappearance of substrate.

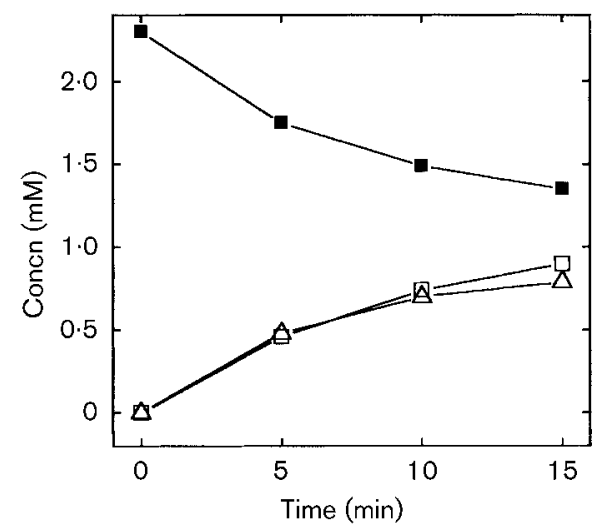

Fig. 2. Transformation of 3-sulfolactate in crude extract of $P$. pantotrophus NKNCYSA. $\square$, 3-sulfolactate; $\triangle$, sulfite; $\square$, pyruvate. 
Racemic sulfolactate was synthesized chemically, and it was inferred that (i) sulfolactate sulfo-lyase is enantiomerspecific, and (ii) a sulfolactate racemase is present at low activity.

The requirement of sulfolactate sulfo-lyase for $\mathrm{Fe}^{2+}$ was examined. No requirement for supplementary iron was detected in crude extract or in desalted crude extract. However, when desalted crude extract was preincubated (10 min) with EDTA ( $1 \mathrm{mM}$ final concentration), $>70 \%$ of the enzyme activity was lost. Readdition of $\mathrm{Fe}^{2+}$ (or $\mathrm{Mn}^{2+}$ or $\mathrm{Co}^{2+}$ to $2 \mathrm{mM}$ final concentration) led to a full recovery of activity.

The inorganic product released from sulfolactate sulfolyase was sulfite. Whole cells, however, released only sulfate. Further, cell extracts containing sulfolactate sulfo-lyase soon contained sulfate after addition of sulfolactate, so we tested for a sulfite dehydrogenase in crude extract, and found the enzyme in sufficient activity $[3 \cdot 3$ mkat ( $\mathrm{kg}$ protein $)^{-1}$ ] to explain the absence of sulfite in the growth medium. The sulfite dehydrogenase was present in cells expected to release sulfite (cysteate and sulfoacetate) and absent in acetate-grown cells. The enzyme was presumed to be inducible.

Pyruvate was dissimilated by extracts of cells of $P$. pantotrophus grown with cysteate or acetate. The metabolism of pyruvate is presumed to be constitutive, which would allow any pyruvate from $\mathrm{C}_{3}$-sulfonates to be dissimilated.

\section{Purification and identification of sulfolactate sulfo-lyase in $P$. pantotrophus}

When proteins in extracts of individual species of bacteria grown with different organosulfonates are separated on SDS-PAGE gels, patterns of proteins specific for each substrate can be observed (Lie et al., 1998; Denger \& Cook, 2001). Extracts of $P$. pantotrophus grown with acetate, cysteate, sulfolactate (Fig. 3, lanes 1-3), sulfoacetate or taurine (not shown) were compared. One major difference was immediately obvious. Only the extracts from cysteateor sulfolactate-grown cells had major $42 \mathrm{kDa}$ (and $8 \mathrm{kDa}$ ) protein bands. When the membrane fraction of the crude extract was separated from the soluble proteins by ultracentrifugation, this $42 \mathrm{kDa}$ protein was found in the supernatant fluid, so it was presumed to be cytoplasmic.

Soluble proteins from the extracts of cysteate-grown cells were separated by anion-exchange chromatography (Fig. 4). Most of the protein eluted at about $0 \cdot 3 \mathrm{M} \mathrm{Na}_{2} \mathrm{SO}_{4}$, where cysteate aminotransferase, glutamate dehydrogenase, sulfite dehydrogenase and the $42 \mathrm{kDa}$ and $8 \mathrm{kDa}$ proteins were found. The highest peak was found to have the $42 \mathrm{kDa}$ and $8 \mathrm{kDa}$ proteins as its major components, and these presumptive subunits co-purified to near homogeneity (Fig. 3, lane 4) on hydrophobic interaction chromatography.

The purified protein was found to catalyse the sulfolactate sulfo-lyase reaction. When followed kinetically, pyruvate

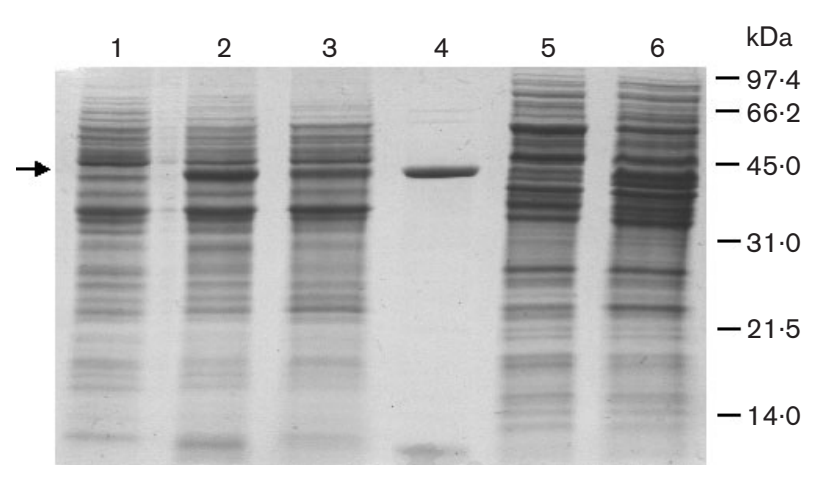

Fig. 3. Electropherogram of proteins in crude extracts of $P$. pantotrophus or C. necator grown under different conditions, and of the purified sulfolactate sulfo-lyase from $P$. pantotrophus. SDS-PAGE was done with crude extracts (30 $\mu \mathrm{g}$ protein) of $P$. pantotrophus grown with acetate (lane 1), cysteate (lane 2) and sulfolactate (lane 3 ), and of $C$. necator grown with acetate (lane 5) and sulfolactate (lane 6). Purified sulfolactate sulfolyase $(5 \mu \mathrm{g})$ (lane 4$)$ was initially recognized as a $42 \mathrm{kDa}$ protein (arrow); the small subunit ( $8 \mathrm{kDa}$ ) was sometimes lost. The positions of the markers of molecular mass are indicated on the right.

was formed from sulfolactate at about 5 mkat (kg protein $)^{-1}$. In discontinuous assays, disappearance of sulfolactate and formation of both pyruvate and sulfite were detected in amounts which confirmed the stoichiometry observed in Fig. 2.

The N-terminal amino acid sequence of the $42 \mathrm{kDa}$ protein was determined to be LDFSNATVKAARREEGGVGV. Three internal fragments were obtained: GNILGGLTTIEEK,

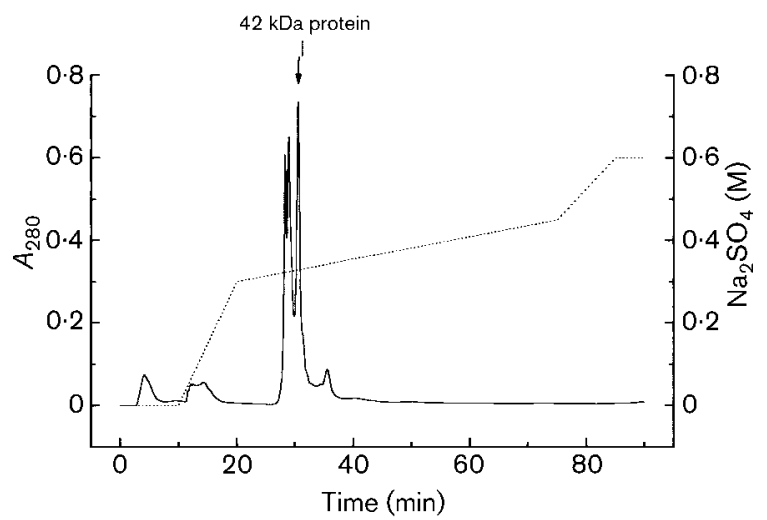

Fig. 4. Separation of the $42 \mathrm{kDa}$ protein from extracts of cysteate-grown cells of $P$. pantotrophus on an anion-exchange column. Soluble proteins $(5 \mathrm{mg})$ from cysteate-grown cells of strain NKNCYSA were applied to a $10 \mathrm{~mm} \times 10 \mathrm{~cm}$ Mono $\mathrm{Q}$ column in $20 \mathrm{mM}$ Tris/sulfate buffer, $\mathrm{pH} \mathrm{7.5}$. Elution of protein by a salt gradient was followed by monitoring $A_{280}$. The presence of the $42 \mathrm{kDa}$ protein (with the $8 \mathrm{kDa}$ protein) was monitored by SDS-PAGE (see Fig. 3). 
ALGNLEK and GDFETIRQAGWK. The only one of these sequences to give similarities to a consistent set of gene products in a BLAST analysis was the first internal fragment, which had similarities to putative galactarate dehydratases (e.g. GarD, SSO1259; Table 1) of the correct length (about 390 amino acids). Galactarate dehydratase is part of the mandelate racemase group within the enolase superfamily (e.g. Babbitt et al., 1996): the mechanism of this subgroup allowed the 'sulfolactate sulfo-lyase' (Suy) hypothesis in Fig. 1 to be generated.

Degenerate primers for PCR were derived from the peptides from the $42 \mathrm{kDa}$ protein. The primer pair suyl-f and suy3-r yielded a $380 \mathrm{bp}$ sequence, whose derived amino acid sequence overlapped with the sequences from the Nterminal peptide and the appropriate internal peptide. The sequence was thus not spurious. PCR primer pair suy2-f and suy4-r allowed the sequence to be extended to $780 \mathrm{bp}$, and primer walking with an adaptor-ligated gene bank (GenomeWalker kit) allowed the $5^{\prime}$ - and the $3^{\prime}$-ends of the gene to be completed. The kit also allowed most of two upstream genes and a downstream gene to be sequenced. The small, upstream gene was presumed to encode the $8 \mathrm{kDa}$ subunit of sulfolactate sulfo-lyase (Suy), and the genes were named $\operatorname{suy} A B$ (Fig. 1b).

The $8 \mathrm{kDa}$ protein (SuyA) was encoded by a gene of $204 \mathrm{bp}$ $(67$ amino acids, calc. $7327 \mathrm{Da})$. Comparison with the databases revealed a significant level of identity of position (39-51\%) with short, (about 90 amino acids) putative proteins (Table 1), which were annotated as the $\mathrm{N}$-terminus of altronate dehydratases. The $42 \mathrm{kDa}$ protein (SuyB) was encoded by a gene of 1182 bp (393 amino acids, calc. 42451 Da). Comparison with the databases revealed (a) a high level of identity of position (31-66\%) with putative proteins (Table 1) which had the correct length (about 390 amino acids) and which were often annotated as 'altronate dehydratases (C-terminal portion)', and (b) significant identity of position with the C-terminal region of characterized altronate and galactarate dehydratases (about 500 amino acids). In each case, the suyAB-like genes were contiguous (Table 1). Identities of up to $79 \%$ with SuyB were detected in environmental sequences (Table 1). It is apparent that suyAB-like genes are widespread in bacteria and in archaea, as well as in environmental samples (Table 1).

Many of the SuyAB-like sequences from Table 1 were compared with sequences of members of the enolase superfamily and with altronate dehydratases in a dendrogram (Fig. 5a). The sequences from seven isolated organisms grouped with SuyAB from $P$. pantotrophus strain NKNCYSA, and separate from representative altronate and galactarate dehydratases (UxaA and GarD), with some other SuyAB-like sequences (e.g. N. aromaticivorans).

\section{A sulfate exporter?}

The gene (1047 bp) downstream of $\operatorname{suy} A B$ could encode a product of 348 amino acids (calc. $36061 \mathrm{Da}$ ) with high levels of identity of position (65-74\%) with putative membrane proteins of unknown function (COG2855, e.g. TauZ in Paracoccus denitrificans NKNIS; Fig. 5b): none of these proteins was represented in the Transport

Table 1. Hypothetical SuyAB-like proteins deduced from sequences in different genomes and environmental samples, and growth with sulfolactate

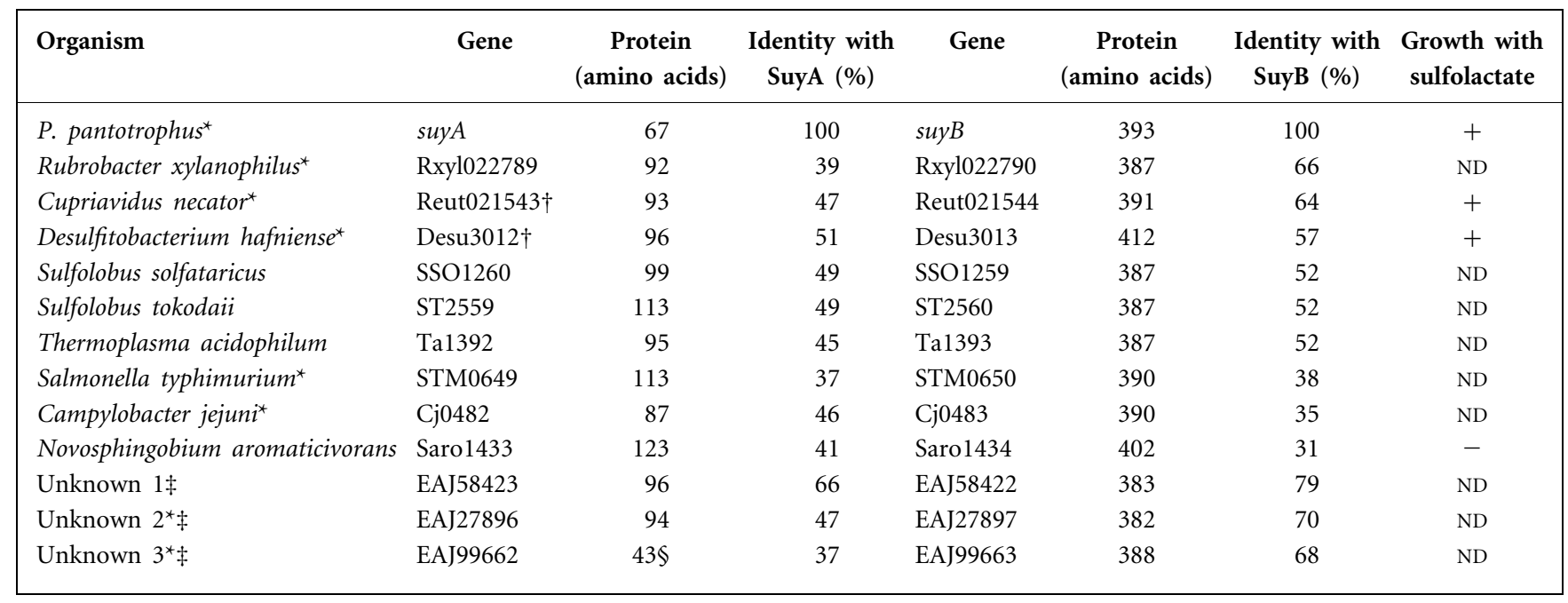

ND, Not done.

${ }^{\star}$ ORF for hypothetical (sulfate) transporter nearby.

$\uparrow$ Several candidates available.

‡Data from Venter et al., 2004.

SIncomplete. 

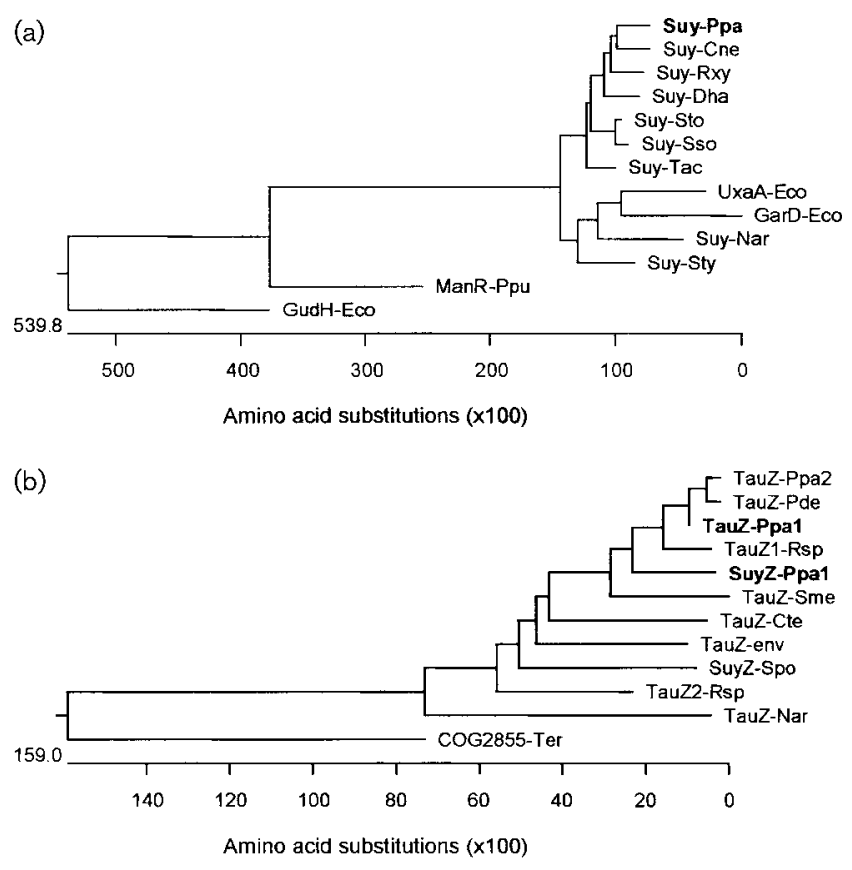

Fig. 5. Dendrograms, generated with CLUSTALW, of several dehydratases and SuyAB-like hypothetical proteins (a), and of SuyZ-like hypothetical proteins (b). The $\mathrm{N}$-terminal sequences of the altronate and galactarate dehydratases correspond to SuyA, so the comparison was generated by considering SuyAB (abbreviated Suy) to be one protein. The abbreviations of the organisms [and the accession number of the relevant sequence(s)] are: Cne, Cupriavidus necator (ZP_00170328, ZP_00170329); Cte, Chlorobium tepidum (NP_661739); Dha, Desulfitobacterium hafniense (ZP_00099861, ZP_00099862); Eco, Escherichia coli; env, environmental sequence (EAF78647); Nar, Novosphingobium aromaticivorans (ZP_00302641); Pde, Paracoccus denitrificans (AAS78783); Ppa, Paracocccus pantotrophus [this paper (Ppa1), AAS78796 (Ppa2; DSM 65)]; Ppu, Pseudomonas putida; Rsp, Rhodobacter sphaeroides [ZP_00006687 (Rsp1), ZP_00005342 (Rsp2)]; Rxy, Rubrobacter xylanophilus (ZP_00186013); Sme, Sinorhizobium meliloti (NP_437511); Spo, Silicibacter pomeroyi (contig 2664, 172877-173860); Sso, Sulfolobus solfataricus (NP_342707, NP_342708); Sto, Sulfolobus tokodaii (NP_378561, NP_378562); Sty, Salmonella typhimurium (NP_459641, NP_459642); Tac, Thermoplasma acidophilus (NP_394846, NP_394847); Ter, Trichodesmium erythraeum (ZP_00328268). The sequences of four characterized enzymes are used: GarD, galactarate dehydratase (EC 4.2.1.42) (P39829); GudH, glucarate dehydratase (EC 4.2.1.40) (P76637); ManR, mandelate racemase (EC 5.1.2.2) (P11444); UxaA, altronate dehydratase (EC 4.2.1.7) (P42604).

Classification Database (June 2004; now TC 9.B.63.-.-). The gene was named suyZ, in analogy to tauZ. A tauZ gene was suspected in strain NKNCYSA (Brüggemann et al., 2004), and it was found in the present study in the gene cluster encoding taurine dissimilation, where it is situated, as predicted, downstream of the gene $(x s c)$ encoding the

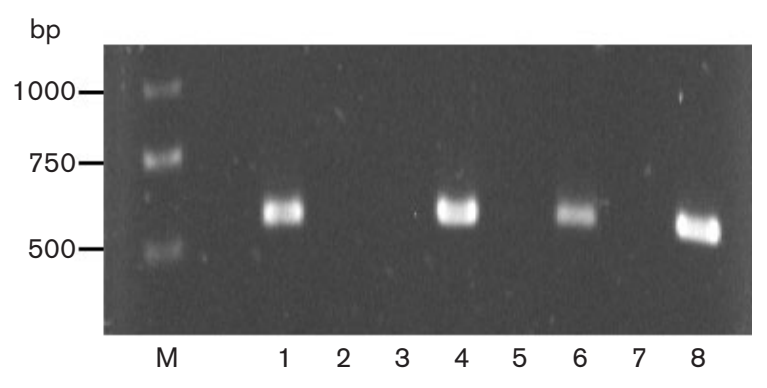

Fig. 6. Electropherogram of DNA fragments from RT-PCR to detect transcription of suyZ and tauZ genes. $P$. pantotrophus NKNCYSA was grown to mid-exponential phase in cysteate-, taurine- or acetate-salts medium. mRNA was separated from the harvested cells and subjected to RT-PCR. Lanes 1, 2 and $3, \mathrm{RT}-\mathrm{PCR}$ for transcript from suyZ with total RNA from cysteate-, taurine- and acetate-grown cells, respectively; lane 4, control PCR reaction with whole cells with the primer pair for suyZ; lanes 5, 6 and 7, RT-PCR for transcript from tauZ with total RNA from cysteate-, taurine- and acetate-grown cells, respectively; lane 8 , control PCR reaction with whole cells with the primer pair for tauZ. Lane $M$, size markers.

desulfonative enzyme (GenBank accession no. AY498615). The two alleles, suyZ and tauZ, shared $73 \%$ identity of position over the sequenced portion of tauZ. The suyZlike genes encode proteins (Fig. 5b), all of which are predicted to encode up to 10 transmembrane helices (THMM program). It was inferred that SuyZ (or TauZ) could be a sulfate exporter (Fig. 1a; see also below), so transcription was examined by RT-PCR.

It was possible to derive PCR primer pairs which distinguished between the transcripts from suy $Z$ and from tauZ. Transcript from suyZ (primer pair suyZ-f and suyZ-r, product $548 \mathrm{bp}$ ) was detected only during growth with cysteate: no transcript was detected in cells growing with acetate or taurine (Fig. 6, lanes 1-3). Conversely, transcript from tauZ (primer pair tauZ-f and tauZ-r, product $539 \mathrm{bp}$ ) was obtained only during growth with taurine: no transcript was detected in cells growing with acetate or cysteate (Fig. 6, lanes 5-7). PCR reactions with whole cells as template for these primer pairs generated products of the correct size (Fig. 6, lanes 4, 8). Co-transcription of suyB and suy $Z$ was then examined (not shown). A PCR reaction with whole cells as template for a forward primer in $\operatorname{suyB}$ (suyB-f) and a reverse primer in suyZ (suyZ-r) generated the anticipated fragment of $1224 \mathrm{bp}$. The same fragment was obtained in a RT-PCR with mRNA from cysteate-grown cells. There was no fragment in samples worked up from acetate-grown or taurine-grown cells. No fragment was obtained from the preparations of mRNA alone, so there was no contamination with DNA in the mRNA preparation. These results confirm the inducible transcription of the suyZ gene (Fig. 6, lanes 1-4), and show that the suyBZ genes are transcribed on a single mRNA molecule. It is inferred that the suyABZ genes represent (part of) an operon. 


\section{A regulator gene}

An incomplete open reading frame (orfR) was found upstream of suyA (Fig. 1b). An NCBI Conserved Domain Search indicated some similarity to several potential transcriptional regulators, but no identity of position with a specific regulator was $>38 \%$. Whereas suy $A B$-like genes were found to be widespread (Table 1), there was no correlation between the occurrence of orfR-like genes and suy $A B$-like genes, so it seems unlikely that the regulator plays a role in sulfolactate metabolism.

\section{Two pathways for cysteate dissimilation in prokaryotes?}

Genes resembling $\operatorname{suy} A B$ were detected in the genomes of a wide range of prokaryotes (Table 1, Fig. 5a), many of which were impractical for us to examine, because they are thermophiles or pathogens. The candidates for suy $A B$ in Cupriavidus necator JMP134, however, could be tested. The organism did not dissimilate cysteate, but it did dissimilate sulfolactate with quantitative substrate utilization and release of stoichiometric amounts of sulfate; inducible formation of a $42 \mathrm{kDa}$ protein was detected by SDS-PAGE in cell extracts (Fig. 3, lanes 5-6). Desulfitobacterium hafniense also grew with sulfolactate, as implied by the presence of suyAB-like genes (Table 1) but not with cysteate. Novosphingobium aromaticivorans, whose suyABlike genes shared the least identity with those in strain NKNCYSA (Table 1, Fig. 5a), grew with neither cysteate nor sulfolactate, so not all suyAB-candidates encode sulfolactate sulfo-lyase.

Bilophila wadsworthia RZATAU and Desulfovibrio sp. strain RZACYSA respire with cysteate (presumably as sulfite) as a sole electron acceptor to yield sulfide (Laue et al., 1997a), and Desulfovibrio sp. strain GRZCYSA ferments cysteate to sulfate and sulfide (Laue et al., 1997b). None of those organisms contained an inducible $42 \mathrm{kDa}$ (or $8 \mathrm{kDa}$ ) protein, but each synthesized a cysteate-induced $35 \mathrm{kDa}$ protein (not shown), as does Desulfovibrio desulfuricans IC1 (Lie et al., 1998). In addition, each organism tested contained a cysteate transaminase. Silicibacter pomeroyi DSS $-3^{\mathrm{T}}$ is reported to dissimilate cysteate (González et al., 2003), but the genome contains no suyAB-like genes. Methanocaldococcus jannaschii DSM 2661 utilizes cysteinesulfinate, via sulfopyruvate, as a sole source of nitrogen for growth with the release of sulfite (R. H. White, personal communication) but the genome does not contain the $\operatorname{suy} A B$ genes. It is inferred that at least one other pathway for the dissimilation of cysteate must exist.

\section{DISCUSSION}

The first catabolic reaction in the cysteate dissimilatory pathway of $P$. pantotrophus NKNCYSA is the constitutive transamination to 3-sulfopyruvate (Fig. 1), coupled to regeneration of 2-oxoglutarate (Fig. 1). It is unclear whether a unique cysteate:2-oxoglutarate aminotransferase (EC 2.6.1.-) is expressed, or whether the reaction is catalysed by a protein with another function (e.g. aspartate transaminase, EC 2.6.1.1) (see for example Weinstein \& Griffith, 1988). The second reaction in the pathway is an NAD-dependent reduction of 3-sulfopyruvate to 3sulfolactate (Fig. 1). Analogous to the first reaction, the enzyme is constitutive, and it is unclear whether a unique 3-sulfolactate dehydrogenase or a malate dehydrogenase (see Introduction) is involved. The specific activities of these enzymes were sufficient to explain the observed growth rate (cf. Mikosch et al., 1999).

The crux of the pathway is the desulfonation reaction, sulfolactate sulfo-lyase (SuyAB; Fig. 1). It is clearly inducible (Fig. 3), and, with the generation of pyruvate, it releases the carbon moiety into amphibolic pathways.

The hypothesis that led us to this reaction and the structure of the pathway derived from the initial sequence data of the strongly induced $42 \mathrm{kDa}$ protein (Fig. 3, lanes 1, 2 and 4), which contrasted with the constitutive initial enzymes in the pathway. The sequence data suggested an enzyme (galactarate dehydratase, GarD) in the mandelate racemase group of the enolase superfamily (e.g. Babbitt et al., 1996): these enzymes have a substrate with a proton and a hydroxyl group on the $\alpha$-carbon of a carboxylic acid. 3-Sulfolactate (Fig. 1) was thus the putative substrate. The mechanism of GarD (Gulick et al., 1998) proceeds from the generation of a stabilized enolate (Fig. 7 shows the adaptation to cysteate) with a $\Delta 1$ double bond, to migration of the double bond to the $\Delta 2$ position. This migration in cysteate, with its sulfonate substituent on C3, would result in elimination of the good leaving group, sulfite, and the generation of an organic moiety (Fig. 7), which would tautomerize to pyruvate. We observed sulfite and pyruvate as the products (Fig. 2), so we presume that the postulated reaction mechanism has some validity. However, as more sequence data became available, the similarity to GarD was superseded by similarity to UxaA (Fig. 5a), an altronate dehydratase representing enzymes which often require $\mathrm{Fe}^{2+}$ for activity (Schomburg et al., 2002). The enzyme assay was then reconstituted to accommodate iron. The phosphate buffer $(\mathrm{pH} 7 \cdot 5)$ was replaced by MOPS ( $\mathrm{pH} \mathrm{6.5),} \mathrm{and}$ $1 \mathrm{mM} \mathrm{Fe}^{2+}$ was present. This was the first time that the

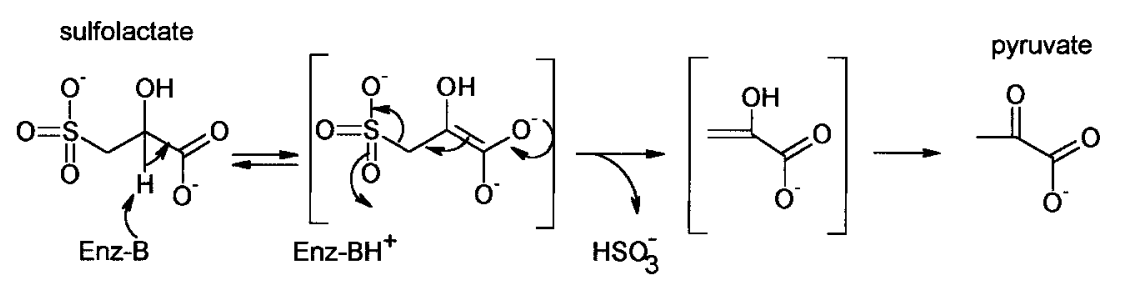

Fig. 7. Putative reaction mechanism of the sulfolactate sulfo-lyase. The relevant literature is cited in the text. 
enzyme could be assayed. Further analysis showed that the iron was tightly bound to the enzyme, so the key to being able to assay the enzyme was not the presence of iron, but the correct choice of buffer. The tightly bound iron in SuyAB contrasts with the loosely bound iron $\left(K_{\mathrm{D}}\right.$ about $4 \mathrm{mM}$ ) in the characterized altronate dehydratases (Dreyer, 1987).

Sulfolactate sulfo-lyase (SuyAB) is not represented in Enzyme Nomenclature (http://www.chem.qmul.ac.uk/ iubmb/enzyme/). The desulfonation (Fig. 7), which is stoichiometric (Fig. 2) and is catalysed by a purified enzyme (see Fig. 3), apparently involves cleavage of a carbon-sulfur bond with formation (however transient) of a carbon-carbon double bond, and thus seems to fall within the carbon-sulfur lyases, EC 4.4.1.-. Sulfolactate sulfo-lyase seems to be an acceptable common name. A systematic name can be suggested when the absolute stereochemistry of the substrate has been established.

C. necator and D. hafniense, whose genomes contain suyABlike genes, were found to utilize sulfolactate, so we presume that the cluster of proteins (Fig. 5a) with high similarity to SuyAB from strain NKNCYSA all encode sulfolactate sulfolyases, and that they are all members of the altronate dehydratase family. There are probably other members of this family whose reactions are unknown, namely the hypothetical proteins encoded by the suy $A B$-like genes in N. aromaticivorans (Table 1, Fig. 5a), and possibly those in Salmonella typhimurium (Table 1, Fig. 5a) and Campylobacter jejuni (Table 1).

Sulfolactate is a component of bacterial spores, so widespread degradative enzymes for this compound are not unexpected. A more recently recognized source of sulfolactate is sulfoquinovose, which disappears during growth, but whose desulfonation is incomplete (Roy et al., 2003). One excretion product is sulfolactate; much more 3sulfopropane-1,2-diol is excreted. One could hypothesize that the substrate for desulfonation in these organisms is 3 -sulfolactate, but that the enzyme loses activity, and that the better excretion form for the organisms to maintain homeostasis is the sulfopropanediol. Cell suspensions of $P$. pantotrophus can rapidly lose the ability to desulfonate (see Results). There is no need to concentrate on sulfolactate as the substrate for desulfonation, because at least one other degradative pathway for cysteate exists, so a different compound could well be desulfonated.

Sulfite dehydrogenase (Fig. 1) is inducible as well, but as it is also induced during growth with taurine, it is regulated separately from the suy genes. Little is known about bacterial sulfite dehydrogenases (Kappler \& Dahl, 2001) or their regulation. In the context of a catabolic pathway, the product of the reaction must be excreted to maintain a constant osmotic pressure in the cell (Fig. 1). Until now, it has been unclear what entity or system fulfilled this function (e.g. Brüggemann et al., 2004).
The cytoplasmic membrane is impermeable to simple organosulfonate compounds (Graham et al., 2002), so a transport system is essential for cysteate to enter $P$. pantotrophus NKNCYSA during growth (Fig. 1). Its nature is still unknown. The cell membrane is also impermeable to sulfate, whose transport into the cell has been studied for a generation (e.g. Pardee et al., 1966) [TC 2.A.53.---]. The problem of exporting sulfate generated during dissimilatory reactions has received little attention (Brüggemann et al., 2004; see also e.g. Homolya et al., 2003). Indeed, Brüggemann et al. (2004) apparently had the answer in their gene cluster(s), because they recognized the need for an exporter, but they did not connect it with the 'domain of unknown function' attributed to the tau $Z$ gene. It took another project, where the generation of sulfoacetate (from taurine) and the exporter of sulfoacetate are purportedly encoded by neighbouring genes (Denger et al., 2004), to awaken the realization of the potential function of TauZ. Further, the mRNA for suy $Z$ is part of a polycistronic message, which includes suyB (Fig. 6), so the gene product, which, as a member of COG2855, is membrane bound, presumably plays an equally important part in the degradative process. Osmotic homeostasis is a major candidate role for this protein, a suggestion which is strengthened by the fact that the corresponding protein, TauZ, is expressed in taurine-utilizing cells.

A transporter requires multiple transmembrane helices. TauZ and SuyZ from strain NKNCYSA are predicted to contain up to 10 transmembrane helices, as do all 12 tested hypothetical proteins in COG2855, which are found in the $\alpha$-Proteobacteria and the Chlorobiaceae (Fig. 5b), as well as in (not shown) the $\beta$-Proteobacteria ( $48 \%$ identity of position), the $\gamma$-Proteobacteria (30\%) and the Clostridiaceae (26\%). The uppermost six TauZ/SuyZ proteins in Fig. 5(b) are all involved in established taurine or sulfolactate pathways. The data seem adequate to hypothesize that suy $Z$ encodes a representative sulfate exporter. The relatively simple structure of the prediction, a single gene product with transmembrane helices but without any similarity to genes in the Transport Classification Database, leads us to the suggestion that SuyZ may represent a member of the poorly understood ion channels (see Kung \& Blount, 2004).

Other phylogenetic groups of bacteria must also have sulfate exporters (ion channels), which have not been recognized, but which are necessary every time organisms require to excrete sulfate during the dissimilation of organosulfonates or sulfate esters. A re-examination of sequences in both real (Burkholderia xenovorans LB400) (Goris et al., 2004) and hypothetical ('Leishmania major' clone P1023) $\beta$ Proteobacteria revealed orfX (COG0730) downstream of $p t a$, in the degradative pathway of taurine (Ruff $e t$ al., 2003). We were then able to predict and confirm the presence of an orfX-like gene downstream of pta in both C. necator JMP134 (Raeut549701) and Burkholderia sp. strain R18194 (Bcepa02005097). It is thus inferred that COG0730 also represents a class of sulfate channels. Many 
other exporters could exist in the many COG groups which encode putative membrane proteins with transmembrane helices, and dissimilatory pathways involving the excretion of phosphate, chloride or nitrite will presumably require them.

P. pantotrophus NKNCYSA is not the only organism in which two alleles of suyZ may be found. Rhodobacter sphaeroides (Fig. 5b) and Sinorhizobium meliloti (not shown) share this phenomenon. In each of the latter two organisms, one of the genes is tauZ, which is interpreted to encode the sulfate channel in taurine degradation; the pathway(s) for which the second candidate is required is unknown. Silicibacter pomeroyi has no tauZ-like gene adjacent to the other tau genes, where an alternative COG group can be postulated for the function. The tauZ/suyZlike gene (Fig. 5b) may thus have a role in the unknown pathway for cysteate metabolism in this organism (see Results).

The short pathway of cysteate degradation (Fig. 1) seems to fall into three sections. Firstly, there is the unknown uptake system with the apparently constitutive expression of the steps releasing the ammonium ion and generating sulfolactate. Secondly there is the inducible sulfolactate sulfolyase, which is cotranscribed with the presumed sulfate export channel. And thirdly, there is the separately induced sulfite dehydrogenase. It seems possible that $P$. pantotrophus NKNCYSA is an organism that contains, in addition to the widespread regulated catabolism of sulfolactate and the separately regulated oxidation of sulfite, constitutive enzymes (possibly including transport) with other primary functions but a broad substrate range, that allow the degradation of cysteate to occur via sulfolactate.

\section{ACKNOWLEDGEMENTS}

We are grateful to S. Baader and O. Popp for data collected during a practical for advanced undergraduates, to $\mathrm{R}$. H. White for a gift of 3-sulfopyruvate, which allowed us to quantify our own materials, and for his permission to cite unpublished data, to G. F. White for advice on synthesis of sulfolactate, and to J. A. Gerlt and H. B. F. Dixon for discussions. We also thank J. R. Batista (Louisiana State University; R. xylanophilus), B. González (P. Universidad Católica de Chile; C. necator), S. Kaplan (University of Texas; R. sphaeroides), M. A. Moran (University of Georgia; S. pomeroyi), M. Romine (Pacific Northwest National Laboratory; N. aromaticivorans) and J. Tiedje (Michigan State University; Burkholderia spp. and D. hafniense), and the contact persons at DOE and TIGR who kindly acknowledged a late draft of this paper with information on our suggested annotation of genes in genome sequencing projects in progress. The research was funded by the University of Konstanz and the European Union (SUITE: ENV4-CT98-0723).

\section{REFERENCES}

Altschul, S. F., Madden, T. L., Schäffer, A. A., Zhang, J., Zhang, Z., Miller, W. \& Lipman, D. J. (1997). Gapped BLAST and PSI-BLAST: a new generation of protein database search programs. Nucleic Acids Res 25, 3389-3402.
Ausubel, F. M., Brent, R., Kingston, R. E., Moore, D. D., Seidman, J. G., Smith, J. A. \& Struhl, K. (1987). Current Protocols in Molecular Biology. New York: Wiley.

Babbitt, P. C., Hasson, M. S., Wedekind, J. E. \& 7 other authors (1996). The enolase superfamily: a general strategy for enzymecatalyzed abstraction of the $\alpha$-protons of carboxylic acids. Biochemistry 35, 16489-16501.

Bonsen, P. P. M., Spudich, J. A., Nelson, D. L. \& Kornberg, A. (1969). Biochemical studies of bacterial sporulation and germination. XII. A sulfonic acid as a major sulfur compound of Bacillus subtilis spores. J Bacteriol 98, 62-68.

Bradford, M. (1976). A rapid and sensitive method for the quantitation of microgram quantities of protein utilizing the principle of protein-dye binding. Anal Biochem 72, 248-254.

Brüggemann, C., Denger, K., Cook, A. M. \& Ruff, J. (2004). Enzymes and genes of taurine and isethionate dissimilation in Paracoccus denitrificans. Microbiology 150, 805-816.

Consden, R., Gordon, A. H. \& Martin, A. J. P. (1946). The identification of amino-acids derived from cysteine in chemically modified wool. Biochem J 40, 580-582.

Cunningham, C., Tipton, K. F. \& Dixon, H. B. F. (1998). Conversion of taurine into $\mathrm{N}$-chlorotaurine (taurine chloramine) and sulphoacetaldehyde in response to oxidative stress. Biochem J 330, 939-945.

Denger, K. \& Cook, A. M. (2001). Ethanedisulfonate is degraded via sulfoacetaldehyde in Ralstonia sp. strain EDS1. Arch Microbiol 176, 89-95.

Denger, K., Laue, H. \& Cook, A. M. (1997). Anaerobic taurine oxidation: a novel reaction by a nitrate-reducing Alcaligenes sp. Microbiology 143, 1919-1924.

Denger, K., Ruff, J., Rein, U. \& Cook, A. M. (2001). Sulfoacetaldehyde sulfo-lyase [EC 4.4.1.12] from Desulfonispora thiosulfatigenes: purification, properties and primary structure. Biochem J 357, 581-586.

Denger, K., Weinitschke, S., Hollemeyer, K. \& Cook, A. M. (2004). Sulfoacetate generated by Rhodopseudomonas palustris from taurine. Arch Microbiol 182, 254-258.

Dreyer, J. L. (1987). The role of iron in the activation of mannonic and altronic acid hydratases, two Fe-requiring hydro-lyases. Eur J Biochem 166, 623-630.

González, J. M., Covert, J. S., Whitman, W. B. \& 8 other authors (2003). Silicibacter pomeroyi sp. nov. and Roseovarius nubinhibens sp. nov., dimethylsulfoniopropionate-demethylating bacteria from marine environments. Int J Syst Evol Microbiol 53, 1261-1269.

Goris, J., Vos, P. D., Caballero-Mellado, J., Park, J., Falsen, E., Quensen, J. F. I., Tiedje, J. M. \& Vandamme, P. (2004). Classification of the PCB- and biphenyl-degrading strain LB400 and relatives as Burkholderia xenovorans sp. nov. Int J Syst Evol Microbiol 54, 1677-1681.

Graham, D. E. \& White, R. H. (2002). Elucidation of methanogenic coenzyme biosyntheses: from spectroscopy to genomics. Nat Prod Rep 19, 133-147.

Graham, D. E., Xu, H. \& White, R. H. (2002). Identification of coenzyme M biosynthetic phosphosulfolactate synthase: a new family of sulfonate biosynthesizing enzymes. J Biol Chem 277, 13421-13429.

Graupner, M., Xu, H. \& White, R. H. (2000a). Identification of the gene encoding sulfopyruvate decarboxylase, an enzyme involved in biosynthesis of coenzyme M. J Bacteriol 182, 4862-4867.

Graupner, M., Xu, H. \& White, R. H. (2000b). Identification of an archaeal 2-hydroxy acid dehydrogenase catalyzing reactions involved in coenzyme biosynthesis in methanoarchaea. J Bacteriol 182, 3688-3692. 
Gulick, A. M., Palmer, D. R., Babbitt, P. C., Gerlt, J. A. \& Rayment, I. (1998). Evolution of enzymatic activities in the enolase superfamily: crystal structure of $(D)$-glucarate dehydratase from Pseudomonas putida. Biochemistry 37, 14358-14368.

Homolya, L., Varadi, A. \& Sarkadi, B. (2003). Multidrug resistanceassociated proteins: export pumps for conjugates with glutathione, glucuronate or sulfate. Biofactors 17, 103-114.

Kappler, U. \& Dahl, C. (2001). Enzymology and molecular biology of prokaryotic sulfite oxidation. FEMS Microbiol Lett 203, 1-9.

Kennedy, S. I. T. \& Fewson, C. A. (1968). Enzymes of the mandelate pathway in bacterium N.C.I.B. 8250. Biochem J 107, 497-506.

Kung, C. \& Blount, P. (2004). Channels in microbes: so many holes to fill. Mol Microbiol 53, 373-380.

Laemmli, U. K. (1970). Cleavage of structural proteins during the assembly of the head of bacteriophage T4. Nature 227, 680-685.

Lamprecht, W. \& Heinz, F. (1984). Pyruvate. In Methods of Enzymatic Analysis, pp. 570-577. Edited by H. U. Bergmeyer. Weinheim: Verlag Chemie.

Laue, H., Field, J. A. \& Cook, A. M. (1996). Bacterial desulfonation of the ethanesulfonate metabolite of the chloroacetanilide herbicide metazachlor. Environ Sci Technol 30, 1129-1132.

Laue, H., Denger, K. \& Cook, A. M. (1997a). Taurine reduction in anaerobic respiration of Bilophila wadsworthia RZATAU. Appl Environ Microbiol 63, 2016-2021.

Laue, H., Denger, K. \& Cook, A. M. (1997b). Fermentation of cysteate by a sulfate-reducing bacterium. Arch Microbiol 168, 210-214.

Lie, T. J., Pitta, T., Leadbetter, E. R., Godchaux, W., III \& Leadbetter, J. R. (1996). Sulfonates: novel electron acceptors in anaerobic respiration. Arch Microbiol 166, 204-210.

Lie, T. L., Leadbetter, J. R. \& Leadbetter, E. R. (1998). Metabolism of sulfonic acids and other organosulfur compounds by sulfatereducing bacteria. Geomicrobiol J 15, 135-149.

Lie, T. J., Godchaux, W. \& Leadbetter, E. R. (1999). Sulfonates as terminal electron acceptors for growth of sulfite-reducing bacteria (Desulfitobacterium spp.) and sulfate-reducing bacteria: effects of inhibitors of sulfidogenesis. Appl Environ Microbiol 65, 4611-4617.

Mikosch, C., Denger, K., Schäfer, E.-M. \& Cook, A. M. (1999). Anaerobic oxidations of cysteate: degradation via a cysteate:2oxoglutarate aminotransferase in Paracoccus pantotrophus. Microbiology 145, 1153-1160.

Pardee, A. B., Prestidge, L. S., Whipple, M. B. \& Dreyfuss, J. (1966). A binding site for sulfate and its relation to sulfate transport into Salmonella typhimurium. J Biol Chem 241, 3962-3969.

Reichenbecher, W., Kelly, D. P. \& Murrell, J. C. (1999). Desulfonation of propanesulfonic acid by Comamonas acidovorans strain P53: evidence for an alkanesulfonate sulfonatase and an atypical sulfite dehydrogenase. Arch Microbiol 172, 387-392.

Roy, A. B., Hewlins, M. J. E., Ellis, A. J., Harwood, J. L. \& White, G. F. (2003). Glycolytic breakdown of sulfoquinovose in bacteria: a missing link in the sulfur cycle. Appl Environ Microbiol 69, 6434-6441.

Ruff, J., Denger, K. \& Cook, A. M. (2003). Sulphoacetaldehyde acetyltransferase yields acetyl phosphate: purification from Alcaligenes defragrans and gene clusters in taurine degradation. Biochem J 369, 275-285.

Sanger, F. (1945). The free amino groups of insulin. Biochem J 39, 507-515.

Schläfli, H. R., Weiss, M. A., Leisinger, T. \& Cook, A. M. (1994). Terephthalate 1,2-dioxygenase system from Comamonas testosteroni
T-2: purification and some properties of the oxygenase component. J Bacteriol 176, 6644-6652.

Schleheck, D., Dong, W., Denger, K., Heinzle, E. \& Cook, A. M. (2000). An $\alpha$-proteobacterium converts linear alkylbenzenesulfonate (LAS) surfactants into sulfophenylcarboxylates, and linear alkyldiphenyletherdisulfonate surfactants into sulfodiphenylethercarboxylates. Appl Environ Microbiol 66, 1911-1916.

Schmidt, E. (1974). Glutamat-dehydrogenase UV-test. In Methoden der Enzymatischen Analyse, pp. 689-696. Edited by H. U. Bergmeyer. Weinheim: Verlag Chemie.

Schomburg, D., Schomburg, I. \& Chang, A. (2002). Lyases II: EC 4.1.3-4.2.1. In Springer Handbook of Enzymes. Edited by D. Schomburg \& I. Schomburg. Berlin: Springer.

Sörbo, B. (1987). Sulfate: turbidimetric and nephelometric methods. Methods Enzymol 143, 3-6.

Stapley, E. O. \& Starkey, R. L. (1970). Decomposition of cysteic acid and taurine by soil microorganisms. J Gen Microbiol 64, 77-84.

Tholey, A., Wittmann, C., Kang, M. J., Bungert, D., Hollemeyer, K. \& Heinzle, E. (2002). Derivatization of small biomolecules for optimized matrix-assisted laser desorption/ionization mass spectrometry. J Mass Spectrom 37, 963-973.

Tralau, T., Cook, A. M. \& Ruff, J. (2003a). An additional regulator, $\mathrm{TsaQ}$, is involved with TsaR in regulation of transport during the degradation of $p$-toluenesulfonate in Comamonas testosteroni T-2. Arch Microbiol 180, 319-326.

Tralau, T., Mampel, J., Cook, A. M. \& Ruff, J. (2003b). Characterization of TsaR, an oxygen-sensitive LysR-type regulator for the degradation of $p$-toluenesulfonate in Comamonas testosteroni T-2. Appl Environ Microbiol 69, 2298-2305.

Vandamme, P. \& Coenye, T. (2004). Taxonomy of the genus Cupriavidus: a tale of lost and found. Int J Syst Evol Microbiol 54, 2285-2289.

Venter, J. C., Remington, K., Heidelberg, J. F. \& 20 other authors (2004). Environmental genome shotgun sequencing of the Sargasso Sea. Science 304, 66-74.

Vollrath, F., Fairbrother, W. J., Williams, R. J. P., Tillinghast, E. K., Bernstein, D. T., Gallagher, K. S. \& Townley, M. A. (1990). Compounds in the droplets of the orb spider's viscid spiral. Nature 345, 526-528.

Weinstein, C. L. \& Griffith, O. W. (1986). $\beta$-Sulfopyruvate: chemical and enzymatic syntheses and enzymatic assay. Anal Biochem 156, 154-160.

Weinstein, C. L. \& Griffith, O. W. (1988). Cysteinesulfonate and $\beta$-sulfopyruvate metabolism. Partitioning between decarboxylation, transamination, and reduction pathways. J Biol Chem 263, 3735-3743.

White, R. H. (1984). Biosynthesis of the sulfonolipid 2-amino-3hydroxy-15-methylhexadecane-1-sulfonic acid in the gliding bacterium Cytophaga johnsonae. J Bacteriol 159, 42-46.

White, R. H. (1986). Intermediates in the biosynthesis of coenzyme M (2-mercaptoethanesulfonic acid). Biochemistry 25, 5304-5308.

Widdel, F. \& Pfennig, N. (1981). Studies on dissimilatory sulfatereducing bacteria that decompose fatty acids. I. Isolation of new sulfate-reducing bacteria enriched with acetate from saline environments. Description of Desulfobacter postgatei gen. nov., sp. nov. Arch Microbiol 129, 395-400.

Wood, D. A. (1971). Sporulation in Bacillus subtilis. The appearance of sulpholactic acid as a marker event for sporulation. Biochem $\mathrm{J}$ 123, 601-605. 